\title{
ORGANIC PRODUCTION AS PART OF A SUSTAINABLE LOCAL FOOD SUPPLY CHAIN
}

\author{
*Lasma Aleksejeva, Modrite Pelse, Agnese Hauka \\ Latvia University of Life Sciences and Technologies, Latvia \\ *Corresponding author's email: lasma.aleksejeva@gmail.lv
}

\begin{abstract}
Organic farming is a sustainable food production system that involves best environmental practices, a high level of biodiversity protection, conservation of natural resources, high animal welfare standards and production according to the desires of a certain group of consumers to consume foods produced by using natural products and processes. The research aims to assess the availability of organic food in the local food supply chain. The research found that the production of organic food is driven by the growing consumer interest in healthy and high-quality food. Consumers prefer short food supply chains to buy organic food from local producers. The range of available organic foods is affected by various micro and macro environmental factors every year. An analysis of organic foods by degree of processing revealed that there were available mostly unprocessed foods (fresh fruit and vegetables) or minimally/ basically processed foods (milk, dairy products, pastries); therefore, the products have low levels of saturated sugars, salt and trans fats.
\end{abstract}

Key words: organic production, sustainability, local food supply chain.

\section{Introduction}

The world's population is not only growing but also changing and urbanizing, and the population's demands and nutritional needs are evolving. The demand for food in urban areas plays an increasing role in determining what foods to grow and how to process, distribute and market the foods. Economic growth, climate change and global trade, however, are changing the way food is produced, processed and sold (Satterthwaite et al., 2010). Agriculture and food production systems affect food availability and profitability (FAO, 2016) as well as food quality and diversity (IBRD/World Bank, 2007; HLPE, 2016, 2017).

Organic farming is a comprehensive system of farm management and food production that involves best environmental practices, a high level of protection of biodiversity, conservation of natural resources, high animal welfare standards and production according to the desires of a certain group of consumers to consume foods produced by using natural products and processes. The organic production method thus plays a dual societal role, where it on the one hand provides for a specific market responding to a consumer demand for organic products, and on the other hand delivers public goods contributing to the protection of the environment and animal welfare, as well as to rural development.

The research aims to assess the availability of organic food in the local food supply chain.

\section{Materials and Methods}

The research used assessments by various research paper authors for the theoretical framework and discussion on sustainable local food supply chains. Trends in the market of organic agricultural products in Latvia in the period 2015-2019 were analysed using the database of the Agricultural Data Centre (ADC) (statistical data on organic farming) and the information available from the Food and Veterinary Service. Research methods employed: monographic, analysis and synthesis, statistical analysis and logical construction.

\section{Results and Discussion}

A food supply chain consists of activities and actors that transport food from the place of production to the place of consumption, including waste disposal (Hawkes \& Ruel, 2012). The stages of a food supply chain include: production; storage and distribution; processing and packaging; and sale (Figure 1). At each stage, a number of actors, both public and private, who are affected by environmental, economic, political and other factors are involved (Porter \& Millar, 1985). The decisions taken by the actors at each stage of a food supply chain affect the ways food is processed and produced, as well as the food environment.

In Latvia, the demand for organically grown and produced food constantly increases, and the organic farming industry and market continues developing. In the period from 2015 to 2019 , the organically certified agricultural land areas in Latvia increased by 52.19 thou. ha or $2.9 \%$, reaching 289.8 thou. ha or $14.5 \%$ of the total agricultural area. Organic farming is characterized by multi-industrial production. Grains (mostly oats, buckwheat) and potatoes accounted for the largest proportion in total crop output. Over a fiveyear period, the quantity of grains produced increased on average by $18.2 \%$, while the quantity of potatoes increased by $7.0 \%$ (Table 1 ).

The output of organic industrial crops (turnip rape, oilseed rape, medicinal plants) significantly increased in Latvia. Over a five-year period, it increased on average by $46.8 \%$, reaching a total of 1482.6 tons 


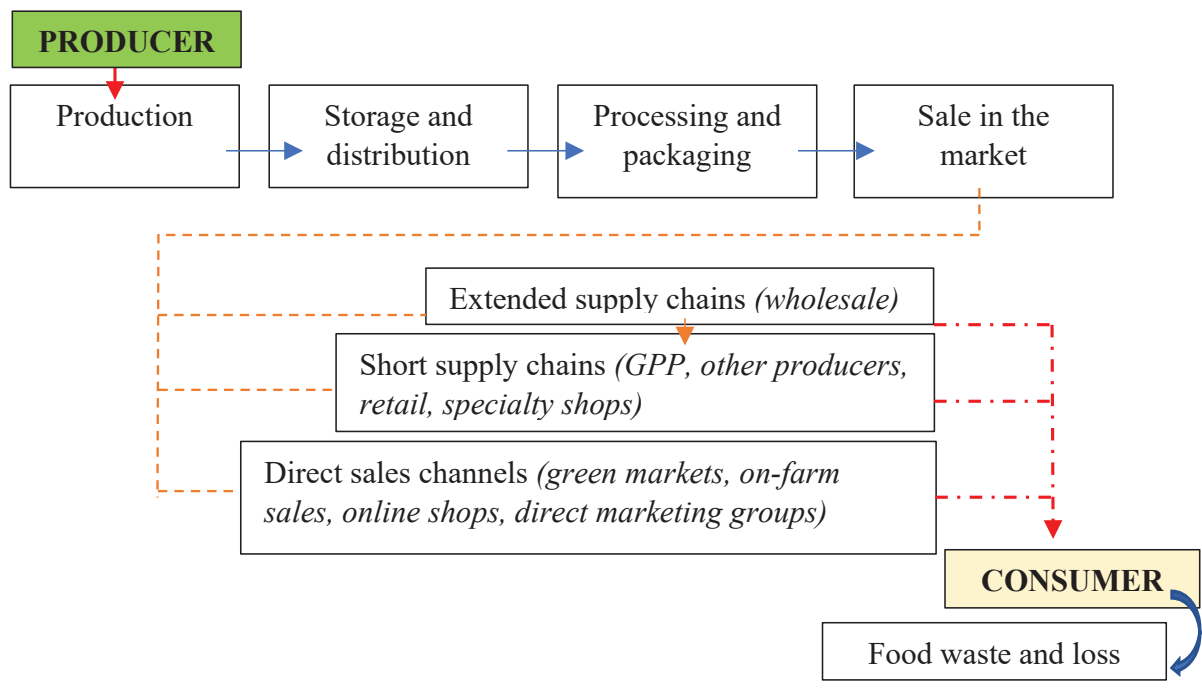

Figure1. Model of a local food supply chain.

Source: authors' construction.

in 2019. Positive trends could be observed in the vegetable and fruit industry, as the output increased, on average by $16 \%$ and $18.5 \%$, respectively, over a five-year period. According to ADC data, the most significant crops produced by farmers were cabbage, pumpkin, carrot, beet and cucumber. Over a five-year period, the output of cucumber (47.4\%) and pumpkin $(31.6 \%)$ increased at the fastest rates, while cabbage production decreased by $3.5 \%$, yet this crop is still considered to be sufficiently significant among the

Output of organic agricultural products in Latvia in 2015-2019, tons

\begin{tabular}{|c|c|c|c|c|c|c|}
\hline Products & 2015 & 2016 & 2017 & 2018 & 2019 & Average change rate, $\%$ \\
\hline Grain & 60202.5 & 61687.2 & 71058.6 & 74356,4 & 111994.6 & 18.2 \\
\hline Industrial crops & 356.4 & 694.7 & 1086.1 & 1098.0 & 1482.6 & 46.8 \\
\hline Vegetables, incl.: & 1842.0 & 2354.9 & 2057.6 & 2159.8 & 3106.5 & 16.0 \\
\hline Cabbage & 269.1 & 255.8 & 271.6 & 250.7 & 231.8 & -3.5 \\
\hline Pumpkin & 379.7 & 648.3 & 382.0 & 555.7 & 840.0 & 31.6 \\
\hline Carrot & 319.0 & 477.3 & 419.2 & 320.4 & 330.7 & 4.3 \\
\hline Beet & 188.2 & 210.8 & 248.3 & 212.2 & 273.8 & 11.1 \\
\hline Cucumber & 93.7 & 152.8 & 110.2 & 114.1 & 286.2 & 47.4 \\
\hline Potato & 18405.5 & 16259.4 & 15130.1 & 20410.7 & 22808.4 & 7.0 \\
\hline Fruits and berries, incl.: & 1528.7 & 2189.7 & 1945.8 & 2985.1 & 2641.8 & 18.5 \\
\hline Apples & 8986.0 & 1446.6 & 1290.5 & 2030.2 & 1796.4 & 24.0 \\
\hline Beef & 3725.1 & 2110.5 & 2165.6 & 2559.2 & 2164.3 & -9.5 \\
\hline Mutton and goat meat & 329.3 & 201.5 & 272.3 & 257.6 & 285.8 & 0.5 \\
\hline Pork & 119.0 & 49.1 & 80.4 & 63.4 & 61.5 & -4.8 \\
\hline Meat of other animals & 13.4 & 4.8 & 17.1 & 25.4 & 16.0 & -9.3 \\
\hline Cow milk & 66769.0 & 72105.0 & 80016.0 & 77235.0 & 83386.0 & 5.9 \\
\hline Goat milk & 243.0 & 258.0 & 381.0 & 349.0 & 346.0 & 11.2 \\
\hline Honey & 291.1 & 273.4 & 343.7 & 409.5 & 359.3 & 6.6 \\
\hline Chicken eggs (thou. pieces) & 809.8 & 1040.7 & 1427.1 & 1649.9 & 2481.5 & 32.9 \\
\hline
\end{tabular}

Source: authors' calculations based on ADC data. 
Output, sales and self-consumption of organic products in Latvia in 2015 and 2019, thou. Tons

\begin{tabular}{|c|c|c|c|c|c|c|c|}
\hline \multirow{2}{*}{ Primary products } & \multicolumn{3}{|c|}{2015} & \multicolumn{3}{|c|}{2019} & \multirow{2}{*}{$\begin{array}{c}\text { Average } \\
\text { change rate, } \% \\
\text { - } \operatorname{tm}(b)\end{array}$} \\
\hline & Output & Sales & $\begin{array}{c}\text { Self- } \\
\text { consumption }\end{array}$ & Output & Sales & $\begin{array}{c}\text { Self- } \\
\text { consumption }\end{array}$ & \\
\hline Grain & 60.20 & 31.62 & 28.58 & 111.99 & 74.72 & 37.27 & 136.31 \\
\hline Industrial crops & 0.36 & 0.17 & 0.19 & 1.48 & 1.35 & 0.14 & 692.70 \\
\hline Vegetables, incl.: & 1.84 & 0.67 & 1.18 & 3.11 & 0.97 & 2.14 & 45.69 \\
\hline Cabbage & 0.27 & 0.07 & 0.20 & 0.23 & 0.06 & 0.17 & -18.34 \\
\hline Pumpkin & 0.38 & 0.10 & 0.28 & 0.84 & 0.27 & 0.57 & 183.12 \\
\hline Carrot & 0.32 & 0.10 & 0.22 & 0.33 & 0.10 & 0.23 & -1.25 \\
\hline Beet & 0.19 & 0.09 & 0.10 & 0.27 & 0.07 & 0.21 & -23.71 \\
\hline Cucumber & 0.09 & 0.06 & 0.04 & 0.29 & 0.06 & 0.22 & 10.69 \\
\hline Potato & 18.41 & 4.69 & 13.72 & 22.81 & 10.48 & 12.33 & 123.37 \\
\hline Fruits and berries, incl.: & 1.53 & 0.91 & 0.62 & 2.64 & 1.34 & 1.30 & 47.04 \\
\hline Apples & 0.90 & 0.48 & 0.42 & 1.80 & 0.79 & 1.01 & 63.83 \\
\hline Beef & 3.73 & 2.85 & 0.87 & 2.16 & 1.88 & 0.29 & -34.22 \\
\hline Mutton and goat meat & 0.33 & 0.28 & 0.05 & 0.29 & 0.19 & 0.10 & -33.16 \\
\hline Pork & 0.12 & 0.06 & 0.06 & 0.06 & 0.01 & 0.05 & -78.28 \\
\hline Meat of other animals & 0.013 & 0.004 & 0.010 & 0.017 & 0.005 & 0.01 & 20.61 \\
\hline Cow milk & 66.77 & 56.4 & 10.23 & 83.39 & 72.25 & 11.14 & 27.78 \\
\hline Goat milk & 0.24 & 0.15 & 0.10 & 0.35 & 0.22 & 0.12 & 53.54 \\
\hline Honey & 0.29 & 0.25 & 0.04 & 0.36 & 0.22 & 0.14 & -11.55 \\
\hline Chicken eggs (thou. pieces) & 0.81 & 0.53 & 0.28 & 2.48 & 1.47 & 1.01 & 178.07 \\
\hline
\end{tabular}

Source: authors' calculations based on ADC data.

vegetables produced. In the fruit and berry category, apples made up the largest proportion. Over a five-year period, apple production increased on average by $24 \%$.

In the livestock industry, cow milk represents a significant proportion in total livestock output. Over a five-year period, the output of cow milk increased on average by $5.9 \%$, totalling 83386 tons in 2019 . Although the area under grazing livestock production represented a significant proportion in the total utilized agricultural area, beef, pork, poultry as well as wild animal meat production decreased over a fiveyear period. This was due to a number of factors: low meat market prices, lack of meat processing facilities and an increase in exports of live animals. The pig industry was significantly affected by the spread of African swine fever (ASF) on farms. Another important obstacle was the problem of purchasing breeding livestock. It is positive that in recent years poultry production, particularly egg production, increased significantly. This was due to the fact that in recent years consumers paid more attention to eggs produced under a free-range system, which led to an increase in the production of organic chicken eggs by $32.9 \%$ over a five-year period.
According to the Common Agricultural Policy factsheet, Latvia is characterized by a large number of self-consumption farms (Factsheet on ..., 2015). An assessment of the situation in organic farming is presented in Table 2. The assessment was based on a case study.

In 2015, market-oriented products were cereals, beef, mutton and goat meat, pork, raw milk, honey and chicken eggs. The sales of the products as a percentage of total production exceeded $50 \%$, while the other products: industrial crops, potato, fruits and berries, vegetables, poultry and wild animal meat were mostly used for self-consumption. In 2019 compared with 2015, the sales of industrial crops and fruits and berries (mostly apples) significantly increased owing to an increase in their output. However, due to a considerable decrease in the number of pigs in recent years, the farmers started producing pork mainly for self-consumption, in contrast to 2015 when $50 \%$ of the pork produced was sold. As regards honey in relation to changes in the certification requirements for organic beekeeping that have been in force since 2018 (bees must be placed no closer than $3 \mathrm{~km}$ from fields where pesticides are applied), it is expected that the 
amount of organically certified honey will continue to decrease. Overall, it could be concluded that farmers use on average $30 \%$ of the total production for selfconsumption, incl. also for animal feed.

Food processing and packaging contribute to food safety and nutritional value through preventing food quality loss and waste and extending the shelf life, increasing nutrient bioavailability and improving food sensory and functional properties and killing food microbes and toxins (van Boekel et al., 2010; Weaver et al., 2014; Augustin et al., 2016). The most common kinds of food processing are grinding, cooling or freezing, smoking, heating, canning, fermentation and extrusion cooking (Augustin et al., 2016).

Over the last five years, the number of companies and farms engaged in the pre-processing and processing of organic products increased from 227 to 351. Despite the positive trend, more than half of the processors were farm-based $(65.35 \%)$ and some of them had the status of home producer (more than $37.61 \%$ of the total processors), which significantly limited their opportunities to retail their products (Table 3).

Over a 5-year period, the number of processors increased by $11.52 \%$. The numbers of processors broken down by product category were variable in the period 2015-2019. In the period of analysis, most processors were engaged in processing fruits, berries, vegetables and potato. Over the five-year period, the number of processors in this product category increased by $9.49 \%$, yet the increase was mostly due to an increase in the number of farm-based processors; therefore, the quantities processed were small. In 2019 , on average, only $30.88 \mathrm{t}$ of agricultural raw materials were processed per processor.
A relatively large proportion of processors belonged to the category "other food products", which included the production of tea, spices and additives, as well as sugar confectionery, the pre-processing, processing and packaging of honey and other beekeeping products. With regard to the production of tea from wild medicinal plants, on 21 April 2015 amendments were made to Cabinet Regulation No. 171, which stipulate that in order for a farmer to receive support for areas under wild medicinal plants, it is necessary to register the facility with the FVS plant for the pre-processing and further processing of medicinal plants. As a result, the number of processors increased in this category, which is logical regarding this product category because in order to remain competitive with relatively small production volumes, one of the ways is to specialize in the production of products from high-quality raw materials.

In the period from 2015 to 2019, the quantities of processed products increased significantly. Of the total output in $2015,4.54 \%$ raw materials were processed, while in 2019 the proportion increased to $14.34 \%$. The calculation did not include the output of eggs, seed, apiculture products (excluding honey) and wild plants (except those for tea production), as the products were not processed.

The degree of food processing can affect the amount of nutrients entering or leaving the food supply chain (van Boekel et al., 2010). Highly processed foods have higher amounts of saturated fat, sugar, and sodium than less processed foods (Poti et al., 2015; Monteiro et al., 2013). Food processing can change the content and bioavailability of nutrients in the food (Augustin et al., 2016) as well as improve the attractiveness and convenience of the food (Mozaffarian, 2016). However, food processing can

Number of organic processors by product category in Latvia in the period 2015-2019

\begin{tabular}{|c|c|c|c|c|c|c|}
\hline \multirow{2}{*}{ Product category } & \multicolumn{5}{|c|}{ Number of processors } & \multirow{2}{*}{$\begin{array}{l}\text { Average change } \\
\text { rate, } \%\end{array}$} \\
\hline & 2015 & 2016 & 2017 & 2018 & 2019 & \\
\hline Meat and meat products & 16 & 22 & 27 & 34 & 24 & 14.19 \\
\hline Fruits, berries, vegetables and potato & 60 & 67 & 69 & 76 & 86 & 9.49 \\
\hline Vegetable oils and animal fats & 2 & 2 & 3 & 4 & 5 & 27.08 \\
\hline Milk and dairy products & 24 & 24 & 22 & 24 & 30 & 6.44 \\
\hline Grain processing products and starch & 11 & 12 & 13 & 13 & 13 & 4.36 \\
\hline Bread and pastry goods and cakes & 13 & 17 & 19 & 18 & 20 & 12.10 \\
\hline Other food products & 89 & 97 & 112 & 128 & 151 & 14.18 \\
\hline Feed & 2 & 3 & 4 & 14 & 6 & 69.05 \\
\hline Beverages & 10 & 12 & 12 & 5 & 16 & 45.42 \\
\hline Total & 227 & 256 & 281 & 316 & 351 & 11.52 \\
\hline
\end{tabular}

Source: authors' calculations based on the FVS database. 
Output of organic products by product category in Latvia in the period 2015-2019, $t$

\begin{tabular}{|c|c|c|c|c|c|c|c|}
\hline \multirow[b]{2}{*}{ Product category } & \multicolumn{5}{|c|}{ Quantity, t } & \multirow{2}{*}{$\begin{array}{l}\text { Change from } \\
\text { base year, } \%\end{array}$} & \multirow{2}{*}{$\begin{array}{c}\text { Quantity ( } t \text { ) per } \\
\text { processor in } 2019\end{array}$} \\
\hline & 2015 & 2016 & 2017 & 2018 & 2019 & & \\
\hline $\begin{array}{l}\text { Meat and meat } \\
\text { products }\end{array}$ & 759.9 & 758.8 & 1362.0 & 1645.7 & 1553.1 & 104.38 & 64.71 \\
\hline $\begin{array}{l}\text { Fruits, berries, } \\
\text { vegetables and } \\
\text { potato }\end{array}$ & 611.9 & 803.4 & 852.1 & 1875.9 & 2655.9 & 334.04 & 30.88 \\
\hline $\begin{array}{l}\text { Vegetable oils and } \\
\text { animal fats }\end{array}$ & 16.7 & 1.9 & 2.9 & 3.6 & 2.0 & -88.02 & 0.4 \\
\hline $\begin{array}{l}\text { Milk and dairy } \\
\text { products }\end{array}$ & 3004.2 & 3411.3 & 3992.9 & 3306.3 & 7380.4 & 145.67 & 246.0 \\
\hline $\begin{array}{l}\text { Grain processing } \\
\text { products and } \\
\text { starch }\end{array}$ & 1862.6 & 3619.3 & 7680.4 & 16767.2 & 23024.3 & 1136.14 & 1771.1 \\
\hline $\begin{array}{l}\text { Bread and pastry } \\
\text { goods and cakes }\end{array}$ & 108.8 & 93.6 & 81.4 & 1161.4 & 1220.1 & 1021.42 & 61.0 \\
\hline $\begin{array}{l}\text { Other food } \\
\text { products }\end{array}$ & 65.1 & 42.7 & 68.7 & 138.5 & 325.6 & 400.15 & 2.15 \\
\hline Feed & 416.9 & 640.6 & 953.9 & 1299.8 & 1577.3 & 278.34 & 262.88 \\
\hline Beverages & 289.9 & 414.2 & 160.7 & 1073.8 & 846.6 & 192.03 & 52.91 \\
\hline Total quantity, $t$ & 7136.0 & 9785.8 & 15155 & 27272.2 & 38585.3 & $\mathrm{x}$ & $\mathrm{x}$ \\
\hline $\begin{array}{l}\text { Quantity } \\
\text { processed as \% of } \\
\text { total output }\end{array}$ & 4.54 & 5.83 & 7.85 & 13.30 & 14.34 & $\mathrm{x}$ & $\mathrm{x}$ \\
\hline
\end{tabular}

Source: authors' calculations based on ADC data.

also reduce the nutritional value of the food, as fibre and essential nutrients are separated, which should then be reincorporated into the food (Mozaffarian, 2016) or ingredients that should usually be restricted for health reasons, including too much sodium and sugar and unhealthy fats, e.g. trans fat (Weaver et al., 2014; Augustin et al., 2016), need to be added.

Among all the product categories in the period from 2015 to 2019, the output of organic grain processing products and starch increased most -1862 tons were produced in 2015, while in 2019 it increased to 23024 tons (Table 4).

The increase was due to the fact that some large processors focused on the production of organic products (Dobeles Dzirnavnieks - organic oat flake products, while Aloja Starkelsen - organic potato starch). There was an increase in output among the other categories of processed agricultural raw materials, except for vegetable oils and animal fats, the output of which in 2019 decreased by $88 \%$ compared with 2015. At the same time, after a steady increase in the output of milk and dairy products until 2018 , there was a significant increase in output in 2019 , reaching 7380 tons of finished products, which was more than twice the quantity produced in 2018 (3306t). The increase in the output of processed food could be explained by the partial specialization of some large processors in organic products. In the opinion of the authors, the motivation of entrepreneurs for boosting organic food processing was caused by the growing interest of consumers in organic products, an opportunity to occupy free market niches and public activities, incl. EU strategies, particularly the EU Biodiversity Strategy for 2030, including the new "From Farm to Fork" strategy. The spread of COVID-19 and the change in consumers' eating and shopping habits also made impacts on the consumption of domestic products.

The packaging of products can influence a consumer's decision to buy or not to buy the product. For example, given that organic products often have a shorter shelf life because no artificial preservatives or other chemicals that prevent spoilage of the products are added, it is important that lower weight or smaller volume packs are available to consumers. This way, the buyer can consume all the food purchased at once and, when shopping again, buy new and fresh produce without worrying that the previously purchased product has already expired and should be discarded. 


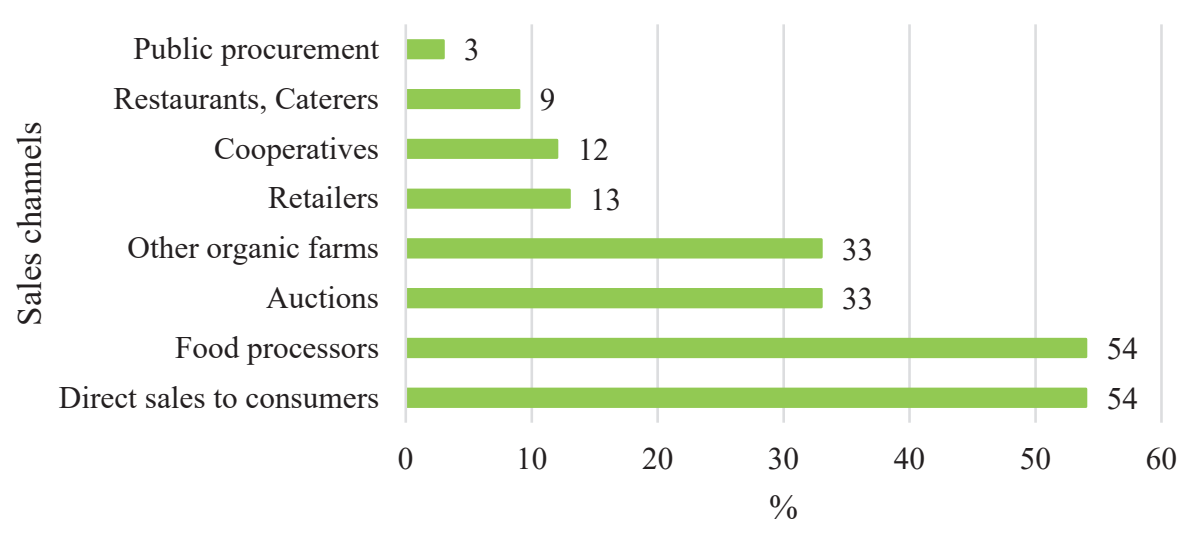

Figure 2. Most popular sales channels for organic products in Latvia.

Source: authors' construction based on Report on the effects ..., 2019.

Farmers use various channels for selling their products (Figure 3 ). The sales channels largely depend on the agricultural industry, the total output and the size of the land area farmed.

In most cases, farms that produce niche products, fruits and berries, vegetables, honey and chicken eggs sell their products directly to final consumers, and often the products represent a secondary source of income. Farms that manage over 30 ha of agricultural land already have a more pronounced specialization; moreover, as the area of agricultural land managed increases, the level of specialization also increases. Farms producing raw milk, beef and mutton, as well as starch potato and cereals mainly sell their products to processors. Often various kinds of feed (hay, haylage, silage, grain and legumes, potato, vegetables, milk, etc.) and breeding livestock are sold to other farms, depending on demand. In Latvia, sales of young beef cattle up to $300 \mathrm{~kg}$ or 7 months of age at auctions are popular. Farmers usually do not practise selling their products to retailers, as most of the products have a short shelf life, as well as the farmers have limited opportunities to regularly deliver a certain quantity of the products. As a result, only a fifth of farms use retail chains for sale. The proportion of sales through cooperatives in total sales is also low, only $12 \%$, because the function of cooperatives is often performed by wholesalers and processors. A small number of farms sell their organic products to caterers and participate in public procurement. For organic farms, participation in green public procurement is hampered by the lowest price policy, delivery logistics, seasonality, paperwork, green procurement requirements for deliveries, the formal attitude of municipalities to organizing and managing a bid of tenders, as well as other factors. This trend could be viewed as negative, as it is caterers, and particularly budget institutions, e.g. schools, kindergartens, social care homes, hospitals, etc., that should set an example of introducing a healthy diet into daily life through including as many organic foods as possible in the diet.

\section{Conclusions}

1. The output of organic products is affected by the growing consumer interest in healthy and high-quality food. Consumers prefer short food supply chains to buy organic produce from local producers.

2. Every year, the range of available organic products is affected by various micro and macro environmental factors: spread of various diseases (ASF, Avian influenza), weather conditions (droughts and rains), availability of production resources (seed, breeding livestock, etc.), various policy decisions on the availability of support, market prices, etc.

3. Over a five-year period, the output of beef, pork, poultry and wild animal meat decreased, while the production of chicken eggs and cow milk increased. In addition, farmers have started producing more fresh fruits and vegetables, as well as medicinal plants, oilseed rape and turnip rape.

4. In 2019 compared with 2015 , main market-oriented products were cereals, beef, mutton and goat meat, raw milk, honey and chicken eggs. The sales of the products as a percentage of total production exceeded $50 \%$, while other products: industrial crops, potato, fruits and berries, vegetables, poultry, wild animal meat and pork were mostly used for self-consumption.

5. The analysis of organic foods by degree of processing revealed that there were available mostly unprocessed foods (fresh fruit and vegetables) or minimally/basically processed foods (milk, dairy products, pastries); therefore, the products have low levels of saturated sugars, salt and trans fats. 


\section{References}

Augustin, M.A., Riley, M., Stockmann, R., Bennett, L., Kahl, A., Lockett, T., Osmond, M., Sanguansri, P., Stonehouse, W., Zajac, I., \& Cobiac, L. (2016). Role of food processing in food and nutrition security. Trends in Food Science \& Technology, 56, 115-125. DOI: 10.1016/j.tifs.2016.08.005.

Factsheet on the Rural Development Programme of Latvia for 2014-2020 (2015). European Commission. Retrieved March 01, 2021, from http://ec.europa.eu/agriculture/ruraldevelopment-2014-2020/countryfiles/lv/factsheet lv.pdf.

FAO. (2016). Influencing Food Environments for Healthy Diets. Rome. Retrieved March 01, 2021, from http:// www.fao.org/3/a-i6484e.pdf.

Hawkes, C., \& Ruel, M.T. (2006). Understanding the Links between Agriculture and Health. 2020 Vision Focus 13. Washington, DC. IFPRI. Retrieved March 01, 2021, from http://ebrary.ifpri.org/utils/getfile/collection/ p15738coll2/id/126913/filename/127124.pdf.

HLPE. (2016). Sustainable Agricultural Development for Food Security and Nutrition: what Roles for Livestock? A report by the High-Level Panel of Experts on Food Security and Nutrition of the Committee on World Food Security. Rome. Retrieved March 01, 2021, from http://www.fao.org/3/a-i5795e.pdf.

HLPE. (2017). Sustainable Forestry for Food Security and Nutrition. A report by the High-Level Panel of Experts on Food Security and Nutrition of the Committee on World Food Security. Rome. Retrieved March 01, 2021, from http://www.fao.org/fileadmin/user_upload/hlpe/hlpe_documents/HLPE_Reports/HLPEReport-11_EN.pdf.

IBRD/World Bank (2007). World Development Report 2008. Agriculture for development. Washington: World Bank, 2007. Retrieved March 01, 2021, from https://openknowledge.worldbank.org/handle/10986/5990.

Lauku attīstības programma 2014-2020 LAP 2014-2020 atbalsta ietekme uz biologiskās lauksaimniecības attīstību. Zinojums. (2019). AREI. (Report on the effects of the RDP 2014-2020 on organic farming development). Retrieved March 01, 2021, from https:/www.arei.lv/sites/arei/files/files/articles/Atskaite_ LAP\%202014-2020\%20ietekme\%20uz\%20BLS_attīstību\%20\%281\%29.pdf. (in Latvian).

Mozaffarian, D. (2016). Dietary and policy priorities for cardiovascular disease, diabetes, and obesity: a comprehensive review. Circulation, 133, 187-225. DOI: 10.1161/CIRCULATIONAHA.115.018585.

Porter, M.E., \& Millar, V.E. (1985). How Information gives you Competitive Advantage. Harvard Business Review. Retrieved March 01, 2021, from https://hbr.org/1985/07/how-information-gives-you-competitiveadvantage.

Poti, J.M., Mendez, M.A., Ng, S.W., \& Popkin, B.M. (2015). Is the degree of food processing and convenience linked with the nutritional quality of foods purchased by US households? Am. J. Clin. Nutr., 101(6), 12511262. DOI: 10.3945/ajcn.114.100925.

Satterthwaite, D., Mcgranahan, G., \& Tacoli, C. (2010). Urbanization and its implications for food and farming. Philosophical Transactions of the Royal Society B., 365, 2809-2820. DOI: 10.1098/rstb.2010.0136.

Van Boekel, M., Fogliano, V., Pellegrini, N., Stanton, C., Scholz, G., Lalljie, S., Somoza, V., Knorr, D., Jasti, P.R., \& Eisenbrand, G. (2010). A review on the beneficial aspects of food processing. Molecular Nutrition \& Food Research, 54(9), 1215-1247. DOI: 10.1002/mnfr.200900608.

Van Boekel, M., Fogliano, V., Pellegrini, N., Stanton, C., Scholz, G., Lalljie, S., Somoza, V., Knorr, D., Jasti, P.R., \& Eisenbrand, G. (2010). A review on the beneficial aspects of food processing. Molecular Nutrition \& Food Research, 54(9), 1215-1247. DOI: 10.1002/mnfr.200900608.

Weaver, C.M., Dwyer, J., Fulgoni, V.L., King, J.C., Leveille, G.A., MacDonald, R.S., Ordovas, J., \& Schnakenberg, D. (2014). Processed foods: contributions to nutrition. American Journal of Clinical Nutrition, 99(6), 1525-1542. DOI: 10.3945/ajcn.114.089284. 